\title{
Alveolodental ankylosis: biological bases and diagnostic criteria
}

\author{
Anquilose alveolodentária: bases biológicas \\ e critérios para o diagnóstico
}

\author{
Duane Cristina Lopes ROSA ${ }^{1}$ iD 0000-0002-6131-0569 \\ Ewerton Raphael SIMUKAWA2 ID 0000-0002-5642-6620 \\ Ana Lúcia Alvares CAPELOZZA² DD 0000-0002-1927-1586 \\ Paulo Sergio Perri de CARVALHO² ID 0000-0003-1775-3108 \\ Moacyr Tadeu Vicente RODRIGUES ${ }^{2}$ iD 0000-0002-4951-5836
}

\section{ABSTRACT}

Alveolodental ankylosis is the fusion of cementum or root dentin with the alveolar bone in both deciduous and permanent teeth. This leads to important clinical and radiographic changes in the affected teeth. Moreover, knowledge of the biological principles involved allows adequate management of teeth affected by this phenomenon.

Indexing terms: Tooth ankyloses. Tooth injuries. Root resorption.

\section{RESUMO}

A anquilose alveolodentária consiste na fusão do cemento ou dentina radicular com o osso alveolar tanto em dentes decíduos como nos dentes permanentes. Isto leva a uma série de alterações clínicas e radiográficas importantes para o diagnóstico. Além disso, o conhecimento dos princípios biológicos envolvidos irá permitir o controle adequado dos dentes acometidos por este fenômeno.

Termos de indexação: Anquilose dental. Traumatismos dentários. Reabsorção da raiz.

\section{INTRODUCTION}

Under normal conditions, the hard tissues (dentin, cementum, and enamel) of permanent teeth do not undergo resorption. When resorption of permanent teeth is observed clinically, it is due to trauma, chronic inflammation of the pulp and/or periodontal tissues, pressure induced in the periodontal ligament associated with orthodontic treatment, tumors, or tooth eruption [1].

Alveolodental ankylosis is the fusion of cementum or root dentin with alveolar bone and is characterized by the loss of the periodontal ligament, which is replaced by

${ }^{1}$ Centro Universitário São Lucas, Curso de Odontologia. Endereço. Porto Velho, RO, Brasil. Correspondência para / Correspondence to: DCL ROSA. E-mail: <duane.rosa@hotmail.com>.

2 Universidade de São Paulo, Faculdade de Odontologia. Bauru, SP, Brasil.

$\boldsymbol{\nabla} \boldsymbol{\nabla} \boldsymbol{v}$

How to cite this article

Rosa DCL, Simukawa ER, Capelozza ALA, Carvalho PSP, Rodrigues MTV. Alveolodental ankylosis: biological bases and diagnostic criteria. RGO, Rev Gaúch Odontol. 2019;67:e2019003. http://dx.doi.org/10.1590/1981-8637201900003162 
bone tissue. Thus, the gomphosis-like articulation between the tooth and alveolar bone disappears with respect to its structural and functional aspects [2]. The first deciduous lower molars are most commonly affected (figure 1), although ankylosis is also a common complication in cases of reimplanted permanent teeth (figures 2) [2].

The pathogenesis of ankylosis is not yet fully understood and may be secondary to many factors. Disorders arising from changes in local metabolism,

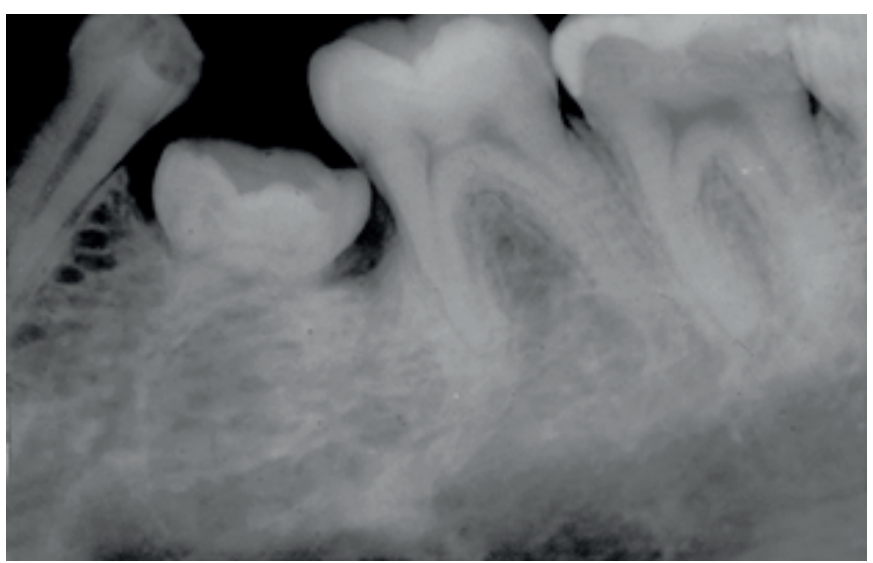

Figure 1. Tooth 75 is ankylosed and in infraocclusion; its roots are already in an advanced stage of replacement by bone tissue. trauma, and chemical or physical irritation have been suggested among others. The periodontal ligament is the most important structure in this context. It is the barrier that prevents connections between bone tissue and root tissues such as cementum and dentin. Loss of this barrier occurs for several reasons; trauma and genetic predisposition are the most cited factors $[5,6]$. These factors will interfere with the balance between the root and alveolar bone, leading to ankylosis and root replacement resorption. Some researchers believe that a genetic predisposition has a significant influence. They presented monozygotic twins demonstrating remarkably similar patterns of ankylosis to confirm such hypotheses [7].

Gault [8] also classified alveolodental ankylosis in post-traumatic ankylosis and idiopathic ankylosis with resorption. The first occurs after trauma to the periodontal ligament that is sufficiently severe and of a sufficient extent to prevent periodontal regeneration. The etiology of idiopathic ankylosis with resorption is still unclear. It occurs when the tooth is submerged or in the process of eruption and always involves the first $2 \mathrm{~mm}$ of the root collar or the furcation region of the molar, that is, the area separating the dental follicle from the tooth's anatomical neck, a region about $2 \mathrm{~mm}$ wide. This observation suggests that ankylotic areas occur in the developing periodontal ligament during eruption when a surface is "neglected" during cementum and periodontal
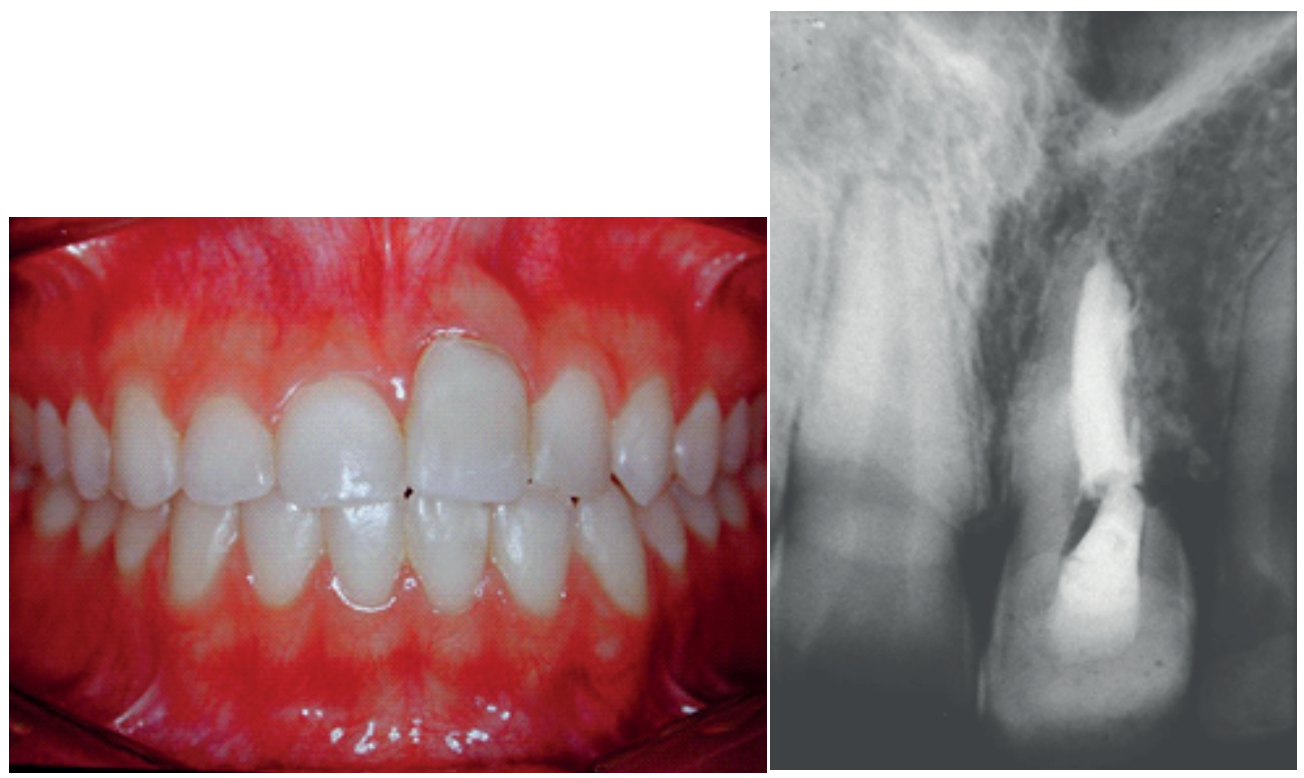

Figure 2. A 19-year-old patient shows an ankylosed tooth 21 after 11 years of avulsion in infraocclusion. The clinical crown was increased by adding incisal composite resin (Henderson [3] attributed a familial tendency only in cases with multiple ankyloses in deciduous teeth. Guedes [4] reported that disorders such as those found in cleidocranial dysostosis might predispose one to ankylosis. 
ligament formation, allowing the neighboring alveolar bone to occupy the space. As no one has ever been able to histologically observe a periodontal space immediately before the formation of an ankylotic bridge, we can only formulate hypotheses about the etiopathogenesis of this phenomenon. The present work discusses the biological aspects involved in the alveolodental ankylosis process, and consequently, replacement resorption. Moreover, radiographic and clinical aspects that aid in diagnosis and clinical management are discussed.

\section{Biological bases}

On the external surface of the root, teeth are surrounded by a periodontal ligament made up of specialized connective tissue that connects the tooth to the alveolar bone and also acts as a barrier between the alveolar bone and cementum. It is believed that periodontal ligament cells are responsible for not only osteogenesis and osteoclasia of the alveolar bone but also for fibrogenesis and fibroplasia of the ligament itself, as well as cementogenesis and the presence of cementoblasts on the root surface. It is also believed that territorial boundaries are established through interactions between bone cells and connective tissue cells in the periodontal ligament, resulting in maintenance of the periodontal space. Moreover, cell boundaries could be induced to expand, retreat, or be destroyed by external stimuli such as inflammation, mechanical stimuli, or trauma [1].

Maintenance of the space and the periodontal ligament depends on several factors, but the epithelial cell rests of Malassez seem to play a fundamental role in this function. They are arranged in the periodontal ligament in cellular cords similar to a net around the dental root. Epithelial cell rests of Malassez participate in the synthesis and release of peptides such as cytokines, growth factors, and arachidonic acid products in the surrounding periodontal connective tissue. Among the peptides involved in the epithelial cell rests of Malassez and maintenance of the periodontal space is epidermal growth factor (EGF). When acting on epithelial cell receptors, this mediator stimulates proliferation in other cells such as osteoclasts and bone and dental resorption when the root surface is not covered by cementoblasts that are carriers of EGF receptors [2,9-11].

The etiologies of the different types of root resorption have two phases: one due to chemical or mechanical damage to the protective tissues of the root (figure 2) and the other due to stimulation from infection or pressure.

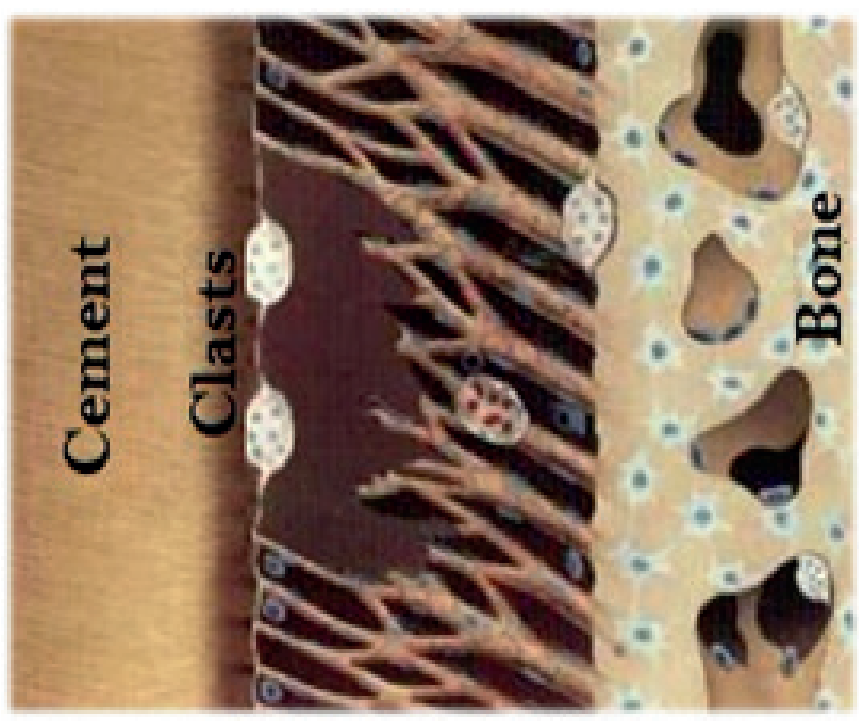

Figure 3. Initial damage to the root surface attacks the clasts

Note: Adapted from Andreasen et al. [12]

The damage occurs in the non-mineralized tissue that covers the outer surface (pre-cement). In severe trauma (intrusive luxation or avulsion with extensive time outside the mouth), damage to the root surface may be so great that repair with cementum replacement is not possible, and the bone may be in direct contact with the root surface without the interposed ligament apparatus. Normally, bone is reabsorbed and physiologically undergoes neogenesis during its remodeling process without any specific stimulation. In cases of severe trauma, osteoclasts are in direct contact with the mineralized dentin (figure 4). Therefore, resorption may occur without any extra stimulation and bone is formed over the exposed dentin [13] (figure 5).

Cementum has a bone-like composition but is reabsorbed more slowly than bone tissue. The cervical two-thirds of the root is covered with acellular cementum. Cellular cementum is mainly found towards the apical third of the root and contains cementocytes housed in lacunas, similar to osteocytes. Below the cementum and adjacent to the root dentin, there is a zone that seals the endings of the dentinal tubules known as Hopewell-Smith's hyaline layer 


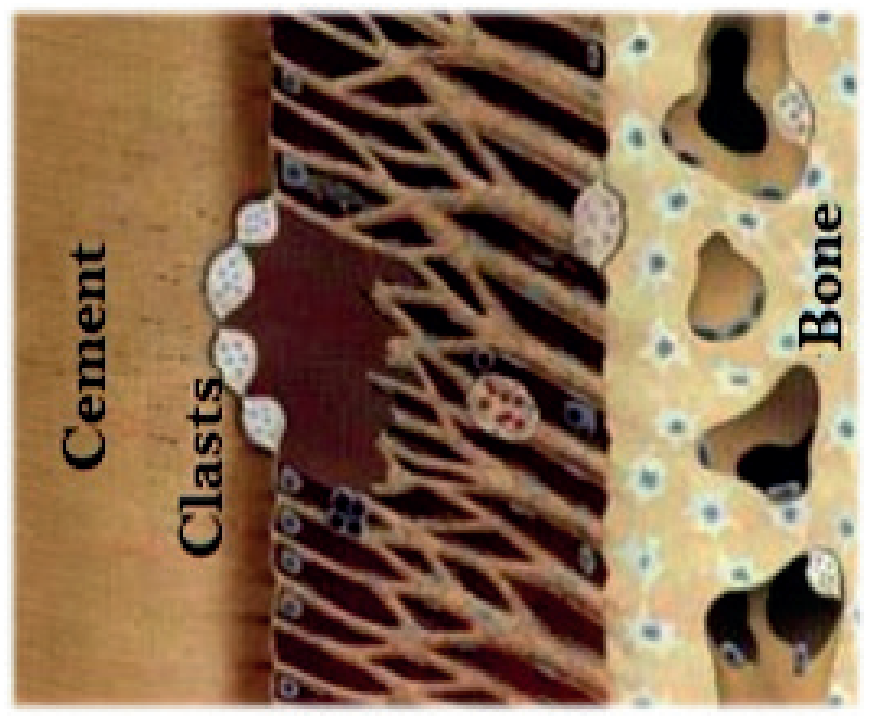

Figure 4. Persistent damage to the root surface attacking the clasts already in the root dentin.

Note: Adapted from Andreasen et al. [12].

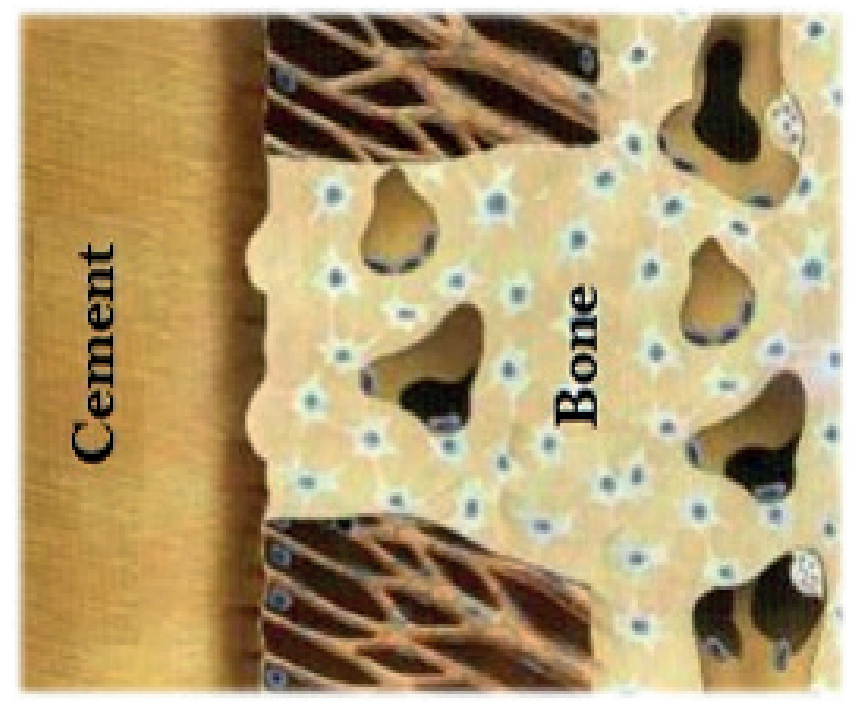

Figure 5. With dentin resorption, there is bone neogenesis stimulation and bone formation occurring over the exposed dentin.

Note: Adapted from Andreasen et al. [12].

or intermediate cementum. The intermediate cementum is hypercalcified compared with the adjacent dentin and cementum and is critical in the prevention of inflammatory resorptions in reimplanted teeth with pulp alterations. This is possibly because of the formation of a barrier against harmful agents from the dentinal tubules that prevents them from entering the periodontal ligament [1].
In luxation-type traumas with loss of viability of periodontal ligament cells and in cases of avulsion with extensive damage to the periodontal ligament from dehydration or inadequate storage of the avulsed tooth, the repair occurs without the intervention of the periodontal ligament. Depending on the extent of the damage, cell lysis occurs at the root surface where the periodontal ligament is necrotic. If the tissue damage is mild (with less than $20 \%$ of the root affected), the resorption will be transient and may repair itself using cells from the adjacent healthy periodontal ligaments. However, in situations where the involved teeth remain outside the alveoli long enough to result in cell necrosis at the root surface, there is an unfavorable prognosis, which may culminate in loss of the tooth after some time. In this case, instead of periodontal ligament connective tissue cells participating in its repair, alveolar bone cells reconstruct the area corresponding to the periodontal ligament and progressively reabsorb the root and replace the area with alveolar bone [1].

The dental and periodontal structures in deciduous teeth are of appropriate dimensions to support masticatory efforts compatible with the chewing patterns of a child. The chewing of an adult with persistent deciduous teeth leads to overloading of the periodontal ligament, leading to the formation of microhemorrhages and areas of necrosis followed by inflammation and repair, which may result in primary or transient ankylosis followed by secondary ankylosis with dental replacement and resorption. In deciduous teeth during the rhizolysis period, the cellularity, vascularization, and innervation of the periodontal ligament diminish through apoptosis of the cementoblasts, odontoblasts, and epithelial cell rests of Malassez. If rhizolysis is associated with an inflammatory pulp process, the resorption process will be accelerated [2].

The periodontal ligament is the only connective tissue that surrounds the roots of the teeth; it is considered the main barrier responsible for the prevention of ankylosis. Therefore, the periodontal space needs to be maintained around the entire root surface. However, the molecular basis of this mechanism is still not well established. No stimulating factor is known leading to resorption after ankylosis. Thus, no method to reverse this process can be suggested [13].

\section{Clinical and radiographic aspects}

Vertical percussion is a physical examination technique that aids greatly in the differential diagnosis of 
alveolodental ankylosis; it is positive when a hollow sound is detected. The altered sonority during percussion is due to the loss of the periodontal ligament; thus, forces are transmitted directly from one mineralized solid body to another and resonate along the tooth and the bone in which it is inserted [2]. Ankylosed teeth lose the mobility of normal teeth. This is another important sign in the diagnosis of replacement resorption. If the process evolves, the teeth might present infraocclusion (figures 1, 2) $[13,14]$. This clinical observation, common in deciduous molars, is an extremely suggestive sign of ankylosis (figure 1) [15].

Aradiographic image of ankylosis is recognized by the fusion of bone trabeculae with the dental structure, the absence of periodontal space, and the lamina dura [2]. The resorption lacunas are filled by bone, which is why the periodontal space is lost (figures 1, 3, and 6).

No distinct radiolucent areas are observed, but the fused root and bone might have a "moth-eaten" appearance (figure 2). In more advanced stages, the whole root might be replaced by bone (figure 1) [13].

However, because of its two-dimensional characteristic, a radiographic image offers little or no help in cases where ankylosis is present in the lingual, palatal, or vestibular regions of the roots. It also offers few resources for the evaluation of teeth that present ankylosis. In these cases, the investigator can use computed tomography (CT), an imaging examination that allows multiplanar reconstruction of the scanned volume, i.e., the visualization of axial, coronal, sagittal, and oblique images, as well as three-dimensional (3D) reconstruction. Traditional CT and cone-beam CT (CBCT) are available. It is unquestionable that tomographic examinations for diagnostic assistance in dentistry have advanced. Through CBCT, it is possible to observe an area of continuity between the dentin and bone, thus diagnosing an area of alveolodental ankyloses [16].Some authors suggest the use of 3D reconstruction for the early diagnosis of alveolodental ankylosis in impacted teeth [17] (figure 7).

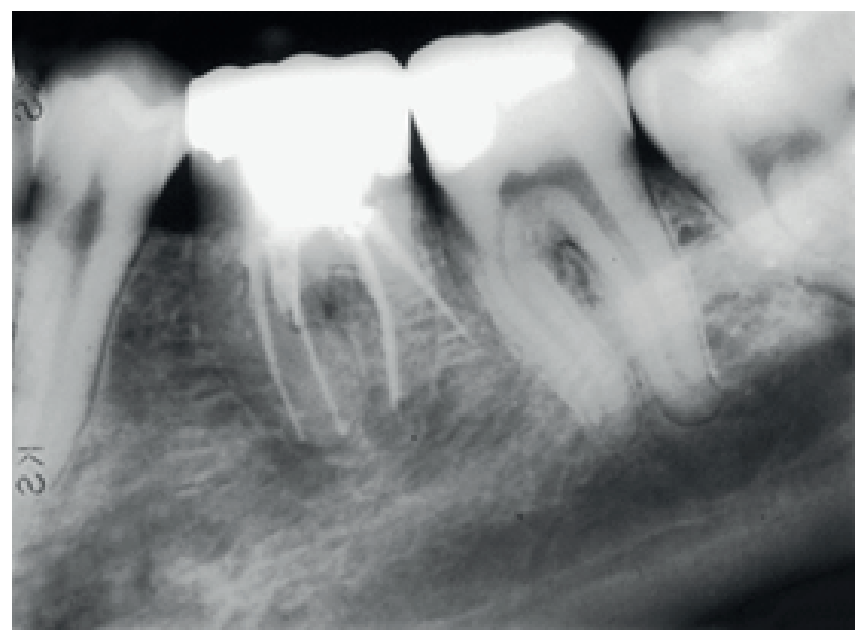

Figure 6. Tooth 36 with a supernumerary root shows areas of fusion with the alveolar bone. This tooth presented a hollow sound on vertical percussion.
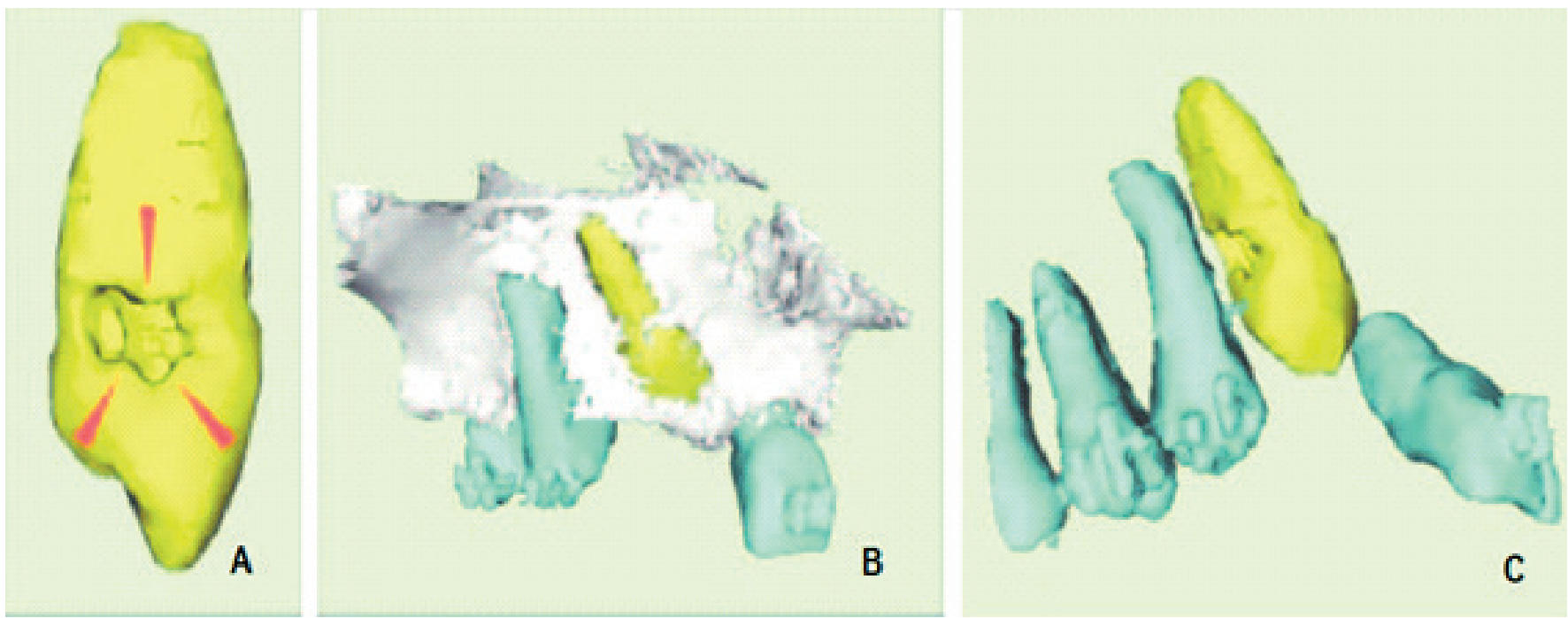

Figure 7. A three-dimensional reconstruction of an area. A. Resorption in tooth 13 due to ankylosis (arrows). B. Anatomical relationships between the bone and teeth. C. Anatomical relationships between the roots.

Note: Adapted from Paris et al. [17]. 
There is no effective treatment for alveolodental ankylosis. Ankylosed teeth may remain in place for many years, and the rate of resorption seems to be dependent on the patient's metabolism [18]. In young patients, reimplanted teeth with a necrotic periodontal ligament may remain in the alveolus for 3 to 7 years, while in patients over 17 years old, ankylosed teeth could remain for decades 1 . In young patients, because the neighboring teeth are still in the eruption phase, the ankylosed teeth frequently are in infraocclusion or the crown is submerged [19].

Clinicians should base their treatment plan on their experience, patients' preferences and perspectives, and implications for research. Although some interventions for the treatment of displaced alveolodental ankylosis have been described for several years, their relative efficacy and safety remain unknown. The lack of high-level evidence for the management of this health problem emphasizes the need for well-designed clinical trials to support clinical practice. It is important that the primary variables, such as tooth survival and patient satisfaction, are evaluated [20].

It is believed that the occurrence of replacement resorption after ankylosis occurs because of the loss of the periodontal protective barrier. That is an imbalance generated between the root and alveolar bone leads to ankylosis and consequently to root replacement resorption. The level of root resorption is variable and cannot be controlled by the patient or the professional. This process can be reversed if less than $20 \%$ of the root is involved. The reduction of periodontal damage after trauma is the only form of prevention. In cases of avulsion, the best clinical management is immediate reimplantation of the tooth or transport of the tooth in milk, saliva, or another appropriate solution to prevent dehydration and consequent death of the periodontal cells. Functional restraint is recommended for 7 to 10 days. Endodontic treatment is required for more severe cases and when the tooth remains outside the mouth for a long duration to prevent pulp infection and potentiation of the resorptive process [13].

Once diagnosed, treatment should be rapid and effective. In 2003, Majorana et al. reported that after avulsion or luxation, $17.2 \%$ of cases developed ankylosis in 5 years; $80 \%$ of the cases occurred after avulsion and $20 \%$ occurred after luxation. Thus, simple educational measures, such as reducing the time the tooth remains outside the mouth and seeking immediate treatment, can minimize ankylosis in cases of avulsion. This would modify the perception of the population regarding the possibility of maintaining teeth affected by severe trauma [21]. Clinical controls are also fundamental in all cases to reduce the damage caused by ankylosis and for the eventual clinical benefit in rehabilitation planning for the most advanced cases.

\section{FINAL CONSIDERATIONS}

Although there is no treatment for alveolodental ankylosis, the affected teeth could remain functional for many years. For this to happen, knowledge of the clinical and radiographic characteristics and biological principles of ankylosis is fundamental for the diagnosis and proper management of involved teeth.

\section{REFERENCES}

1. Unraj MN. Dental root resorption. Oral Surg Oral Med Oral Pathol Oral Radiol Endod. 1999;88(6):647-53. http://dx.doi. org/10.1016/S1079-2104(99)70002-8

2. Consolaro A. Reabsorções dentárias nas especialidades clínicas. Maringá: Dental Press; 2002.

3. Enderson HZ. Ankylosis of primary molars: a clinical, radiographic, and histologic study. ASDC J Dent Child. 1979;46(2):117-22.

4. Guedes-Pinto AC. Odontopediatria. $2^{\text {a }}$ ed. São Paulo: Santos; 1990.

5. Neville BW, Damm DD, Allen CM, Bouquot JE. Patologia oral \& maxilofacial. 2 ${ }^{a}$ ed. Rio de Janeiro: Guanabara-Koogan; 2004.

6. Raghoebar GM, Boering G, Vissink A. Clínica, radiográfica e histológica características de retenção secundária de molares permanentes. J Dent. 1991;19(3):164-70. http://dx.doi.org/10. 1016/0300-5712(91)90007-L

7. Dewhurst SN, Harris JC, Bedi R. Infra-oclusão dos molares decíduos em gêmeos monozigóticos: relato de dois casos. Int J Paediatr Dent. 1997;7(1):25-30. http://dx.doi.org/10.1111/j. 1365-263X.1997.tb00269.x

8. Gault P. Idiopathic ankylosis-resorption: diagnosis and treatment. Orléans, France: Elsevier Masson SAS; 2013.

9. Lindskog S, Blomlöf L, Hammarström L. Dentin resorption in replanted monkey incisors. Morphology of dentinoclast spreading in vivo. J Clin Periodontol. 1988;15(6):365-70. http:// dx.doi.org/10.1111/j.1600-051X.1988.tb01013.x

10. Fujiyama K, Yamashiro T, Fukunaga T, Balam TA, Zheng $L$, Takano-Yamamoto T. Denervation resulting in dento-alveolar ankylosis associated with decreased Malassez epithelium. J Dent Res. 2004;83(8):625-9. http://dx.doi.org/10.1177/154 405910408300808

11. Beertsen W, Piscaer $M$, van Winkelhoff AJ, Everts $V$. Generalized cervical root resorption associated with 
periodontal disease. J Clin Periodontol. 2001;28(11):1067-73. https://doi.org/10.1111/j.1600-051X.2001.281112.x

12. Andreasen JO, Andreasen FM. Traumatismo dentário: soluções clínicas. São Paulo: Panamericana; 1991.

13. Fuss Z, Tsesis I, Lin S. Reabsorção da raiz: diagnóstico, classificação e escolhas de tratamento baseadas em fatores de estimulação. Dent Traumatol. 2003;19(4):175-82. http:// dx.doi.org/10.1034/j.1600-9657.2003.00192.x

14. Eichenbaum IW. Tooth eruption and ankylosis. J Prev Dent. 1977t;4(5):39-45.

15. Caldas ZD. Estudo radiográfico em indivíduos portadores de molares decíduos superiores anquilosados submersos [tese]. São Paulo: Universidade de São Paulo; 1989.

16. Silva DC. Exames por imagem no diagnóstico de anquilose alveolodentária: relato de caso clínico. Rio Grande do Sul: Universidade Federal do Rio Grande do Sul; 2015.

17. Paris M, Trunde F, Bossard D, Coudert Jl. L'ankylose dentarie: diagnostic par tomodensitométrie et reconstruction tridimensionnelle. Paris: Elsevier Masson SAS; 2010.
18. Tronstad L. Root resorption--etiology, terminology and clinical manifestations. Endod Dent Traumatol. 1988;4(6):241-52.

19. Kawanami M, Andreasen JO, Borum MK, Schou S, HjørtingHansen $E$, Kato $H$. Infrapposição de incisivos superiores permanentes anquilosados após reimplante relacionados à idade e ao sexo. Endod Dent Traumatol. 1999;15(2):50-6.

20. De Souza RF, Travess H, Newton T, Marchesan MA. Interventions for treating traumatised ankylosed permanent front teeth. Cochrane Database Syst Rev. 2010 Jan 20;(1):CD007820. http://dx.doi.org/10.1002/14651858.CD007820.pub2

21. Majorana A, Bardellini E, Conti G, Keller E, Pasini S. Root resorption in dental trauma: 45 cases followed for 5 years. Dent Traumatol. 2003 Oct;19(5):262-5. http://dx.doi.org/10. 1034/j.1600-9657.2003.00205.x

Received on: 8/7/2018 Final version resubmitted on: 20/10/2018 Approved on: 17/11/2018 